\title{
PESANTREN AND PEACE EDUCATION DEVELOPMENT: Challenges, Strategies and Contribution to Deradicalization in Indonesia
}

\author{
Muhammad Thoyib \\ State Institute for Islamic Studies (IAIN) Ponorogo \\ Jl. Pramuka No. 156, Ronowijayan, Ponorogo, East Java, Indonesia \\ E-mail: thoyib@iainponorogo.ac.id
}

\begin{abstract}
Pesantren and Peace Education Development: Challenges, Strategies and Contribution to Deradicalization in Indonesia. Developing peace education in society is the 'main gateway' of Indonesian civilization in the future to create tolerant, moderate and inclusive human beings. This study aims to identify challenges, strategies, and contribution to developing peace education for deradicalization in Pesantren al-Bidayah Pasuruan and Pesantren Miftahul Ula, Nganjuk, East Java which are famous as 'humanist pesantrens' with unique diversity of religious thoughts, cultures, and beliefs around them. This research is a qualitative research using interactive analysis model that consists of data reduction, data display and data verification. The conclusions of this study are: First, the challenges of peace education development at Pesantren al-Bidayah Pasuruan and Pesantren Miftahul Ula Nganjuk encompass several forms: the ideological challenge of religious social fundamentalism, religious political cannibalism, and exclusive religious education. Second, the strategies of implementing peace education development at the two pesantrens include: learning to understand cultural diversity, learning to understand religious plurality, and learning to understand social economic-based community. Third, the contribution of peace education development at the two pesantrens includes: contribution of building non-violence culture, developing cultural appreciation of human rights, and awakening democratic values and tolerance around society.
\end{abstract}

Keywords: pesantren; peace education development; challenges; strategy; and contribution.

\begin{abstract}
Abstrak: Pesantren dan Pengembangan Pendidikan Perdamaian: Tantangan, Strategi dan Kontribusi terhadap Deradikalisasi di Indonesia. Pengembangan pendidikan perdamaian di masyarakat merupakan 'pintu gerbang utama' peradaban Indonesia di masa depan untuk menciptakan manusia yang toleran, moderat dan inklusif. Penelitian ini bertujuan untuk mengidentifikasi tantangan, strategi, dan kontribusi pengembangan pendidikan perdamaian untuk deradikalisasi di Pesantren al-Bidayah Pasuruan, dan Pesantren Miftahul Ula, Nganjuk, Jawa Timur yang terkenal sebagai 'pesantren humanis', dengan keunikan keragaman agama, budaya, serta kepercayaan masyarakat sekitarnya. Penelitian ini merupakan penelitian kualitatif dengan menggunakan model analisis interaktif yang terdiri dari reduksi data, display data dan verifikasi data. Kesimpulannya adalah: Pertama, tantangan pengembangan pendidikan perdamaian di Pesantren al-Bidayah Pasuruan dan Pesantren Miftahul Ula, Nganjuk, Jawa Timur meliputi beberapa bentuk: tantangan ideologi fundamentalisme sosial agama, ideologi kanibalisme politik agama, dan ideologi pendidikan agama eksklusif. Kedua, strategi pengembangan pendidikan perdamaian di dua pesantren mencakup beberapa hal yang meliputi: strategi pembelajaran memahami keanekaragaman budaya, pembelajaran memahami pluralitas agama, dan pembelajaran memahami masyarakat berbasis sosial ekonomi komunitas. Ketiga, kontribusi pengembangan pendidikan perdamaian di dua pesantren tersebut meliputi: kontribusi pembangunan budaya tanpa-kekerasan, pengembangan apresiasi budaya terhadap hak asasi manusia, dan membangkitkan nilai-nilai demokrasi dan toleransi masyarakat sekitarnya.
\end{abstract}

Kata kunci: pesantren; pengembangan pendidikan perdamaian; tantangan; strategi; dan kontribusi.

\section{Introduction}

The role and function of religion in the last few decades have begun to be questioned. This is related to cases of violence and conflicts in the name of religion that often occurs in society. Indonesia seems to be a country that is still not able to manage plurality properly. Especially after the fall of the New Order regime, acts of terrorism and religious radicalism spread in this country like in spring. Within no more than a decade, a series of bomb attacks have shaken this pluralist republic. To name just a few, these 
include Bali bombing I-II, Australian Embassy bombing, Hotel JW Marriot I-II, Hotel Ritz Carlton bombing, "book bomb" addressed to a number of figures, "Friday bombing" at Masjid Mapolres Cirebon, and suicide bombing in Gereja Bethel Injil Sepenuh (GBIS) Kepunton, Solo in 2014, the abduction associated with brain washing methods allegedly related to Islamic State of Indonesia (NII) in 2015, the attack on church in Yogyakarta in 2018, and the bombing of a church that was so grievous in the Surabaya in 2018 that sacrificed tens of innocent people.

In addition to a series of terrorism cases as mentioned above, religious radicalism also spreads everywhere. Examples included attacks on the Ahmadiyah congregation in Cikeusik, Pandeglang, Banten (2012-2015) as well as attacks on allegedly Shi'ite pesantren in Pasuruan (2014) and Sampang (2013-2015). The number of conflicts that occurred in Indonesia shows that this nation has not fully understood the meaning of diversity and difference. Not a few among humans who want to abolish diversity and replace it with unity and uniformity. Ironically, the terrorists and the radicals claimed that all was done because of the command of religion (Islam). ${ }^{1}$

Such a thing of course cannot be allowed. Indonesia must improve itself to become a better nation. Among the dimensions of life that must be addressed are the world of education, both formal, informal and nonformal. Whether recognized or not, education contributes to the formation of an exclusive or inclusive mindset. In this context, according to researcher, peace education needs attention. Therefore, religious education is currently in fact not able to produce people who are tolerant, moderate, and inclusive. The proof of this, in addition to the outbreak of terrorism acts and Islamic radicalism, is that lately there is a tendency of systematic efforts by certain denominations to teach hardline religious doctrines among high school students (SMA).

Azyumardi Azra says that school children

\footnotetext{
1 Ngainun Naim, "Strategi Penanganan Radikalisme dan Terorisme di Indonesia: Perspektif Pendidikan", National Simposium on "Memutus Mata Rantai Radikalisme dan Terorisme", Jakarta, July 15, 2012. Syarif Hidayatullah State Islamic University of Jakarta.
}

are specifically targeted for the recruitment of terrorist and radical groups. The professor of State Islamic University of Syarif Hidayatullah argued that several studies have proven the existence of recruitment efforts at schools by "brainwashing" the students with a certain radical ideology. ${ }^{2}$ This is reinforced by the research results of The Wahid Institute in cooperation with the Ministry of Research and Development of Religious Affairs Department in 2016 which confirmed that there are $10 \%$ of 2,520 high school students in 34 provinces in Indonesia are willing to take radical action. ${ }^{3}$ In addition, data compiled by The Wahid Institute in 2016 shows clearly the increasing graph of violence in the name of religion, differences in beliefs, and intolerance. ${ }^{4}$ Even the latest research and evaluation conducted by the State Intelligence Agency (BIN) stressed that the number of radicalism among teenagers in Indonesia in 2017 increased sharply with $75 \%$ being indicated as infected by the virus of radicalism. ${ }^{5}$

These data at least show that religion has played its antagonistic function. On the one hand, religion promises happiness, compassion, and peace. On the other hand, religion has shown its "ferocious" face that has played a role as a trigger of conflict, hostility, and violence (radicalization) in the name of religious truth under the pretext of "defending God". Herein lies the challenge for religion to prove itself as an advanced, progressive, humanist, positive, open and humble force while also maintaining its relevance to help people solve their socialreligious problem. ${ }^{6}$

Ricardo L. Garcia on his book, Teaching in Pluralistic Society, states that in order to improve social relations and social facts that are relatively prejudicial, discriminatory and

\footnotetext{
${ }^{2}$ Azyumardi Azra, "Rekruitmen Anak Sekolah", Republika, April 24, 2012.

${ }^{3}$ Report Document of Balai Litbang Kemenag in 2017 on www/http.balitbang.kemenag.go.id. accessed April 13, 2017.

4 The Wahid Institute, "Terorisme dan Radikalisme: Tantangan Kekinian Islam Nusantara", on National Seminar, Jakarta, Augustus 19, 2016. Syarif Hidayatullah State Islamic University of Jakarta.

${ }^{5}$ Republika, March 232018.

${ }^{6}$ Michael Philip, Peace Education on Social Media Challenge, (New York: Wilcohn Press, 2016), p. 29. See also on Muhammad Thoyib, Model Pengembangan Pendidikan Islam Multikultural di Indonesia. (Ponorogo: STAINPo Press, 2016), p.57.
} 
marginalized, it is necessary to consider a way in social education and religious education that contains a reconciliatory, mediative, consensual, accommodative, and negotiative attitude. ${ }^{7}$ These five attitudes are what researcher says will happen when religious education contains the values of peace. Because in the values of peace there must be reconciliation, which reconciliation requires a mediation that creates a collective agreement that can accommodate each different group and in reconciliation must pass negotiations. When these five things can manifest in religious education and peace education, while the changes will occur.

In this context, the researcher is interested to conduct a research about peace education development model in the effort of religion deradicalization at Pesantren al-Bidayah, Pasuruan and Pesantren Miftahul Ula Nganjuk East Java with the following important considerations. First, the two pesantrens since 1998 are pesantrens that have high commitment in developing peace education through religious dialogue and interreligious social-economic cooperation. The commitment of two pesantrens were based on the concerns of people condition and nation that experienced various social conflicts, disputes, acts of violence and radicalization in the name of religion, especially in Pasuruan and Nganjuk areas of East Java, such as the Ahmadiyya-Sunni conflict (in 2000 s untill the present), the ShiaSunni conflict (from the 1990 s to the present), the establishment of several mosques by LDII in Nganjuk residents in 2005, the threat of the burning of the Catholic Church in 2008, the threat of expulsion of radical Anshorullah in 2013, and so on.

Second, the commitment of both pesantrens is supported by the cultural slogan of "Togetherness in Diversity and Indonesianness" which involves people of various religions, including believers (panghayat) dan Confucianism. These two pesantrens take the view that the brotherhood is not confined to the five religions, but also extended to anyone who wishes to be good and worship God sincerely and honestly and put

7 Ricardo L. Garcia, Teaching in Pluralistic Society, (New York: Harper \& Row Plubisher, 2012), p.129. forward the peace of nation and state life. Third, the two pesantrens are committed to the efforts of realizing peace and social harmony developed through the 'liwetan' culture (cooking and eating together on taro leaves) as a symbol of 'unity, togetherness, and proximity' held every month, from one village to another. ${ }^{8}$

\section{Method}

The type of research is a field research with a qualitative approach where the research seeks to describe the phenomenon that exists naturally in the positive model of case study about the model of peace education development in Pesantren al-Bidayah, Pasuruan and Pesantren Miftahul Ula Nganjuk, considering that these pesantrens are often referred to as humanistic pesantrens in East Java. ${ }^{9}$ This study uses a phenomenological approach that aims to describe the situation or phenomenon that occurs. Bogdan and Biklen assert that " $A$ research with phenomenological approach efforts to understand the meanings of interrelated phenomenon with people in certain situation." 10 This approach is an appropriate way to determine and analyze; (1) the challenges of peace education development; (2) the strategies of peace education development; and (3) the constributions of peace education development. The three points of the study are interrelated where various challenges to the development of peace education that occur will not be resolved properly without being supported by the right strategies. With the right strategies, the two pesantrens can make a positive contribution to peace education such as the birth of mutual respect for differences and not being easily pitted against each other, and so on. Analysis of the data in this study used an interactive model that

${ }^{8}$ The history of establishment and development of the two pesantrens are summarized from the information and interviews and dialogs with $\mathrm{KH}$. Abdul Qodir as the leader of Pesantren Miftahul Ula Nganjuk on 20 February 2017 and KH. Haris Imauddin, MA, as the leader of Pesantren al-Bidayah, Pasuruan, April 7, 2017.

9 Buliten Ar-Risalah, Pesantren al-Bidayah, Pasuruan, East Java, July 2016. And also Buletin Ulul Albab, Pesantren Miftahul Ula, Kertosono, Nganjuk, East Java, January, 2017

${ }^{10}$ Bogdan. R.C. and Biklen. S.K., Qualitative Research for Education: An Introduction to Theory and Methods, (Boston: Aliyn and Bacon, 1998), p.25. 
consists of three activities, namely; (1) reduction of data (data selection according to the theme); (2) display of data (data presentation); and (3) drawing conclusions/verification. This interactive model of analysis is based on the idea of Miles and Huberman. ${ }^{11}$

\section{An Overview of Pesantren Miftahul Ula and Pesantren al-Bidayah: The Humanistic Pesantrens}

\section{Profile of Pesantren Miftahul Ula, Nganjuk, East Java}

Pesantren Miftahul Ula is a humanistic pesantren which was born and developed in line with struggles for of this republic's independence in 1940 in Nglawak village, Kertosono, Nganjuk, East Java. This pesantren was born on the initiation of $\mathrm{KH}$. Abdul Fattah Jalain who was given the mandate directly by $\mathrm{KH}$. Hasyim Asy'ari of Tebu Ireng Jombang, who was his teacher as well as 'parent' as an effort to counter the communism movement agitated by the Indonesian Communism Party (PKI) in the region. At that time, the region, especially Kertosono, was the largest area of communism in East Java and the number of abangan there was quite large. ${ }^{12}$

Pesantren Miftahul Ula, Nglawak, Kertosono, Nganjuk East Java since its establishment has experienced significant development in terms of its quality and quantity. As the oldest pesantren in Nganjuk district, Pesantren Miftahul Ula has around 4,500 students with various social, cultural and economic backgrounds. Distribution of the origin of students is also quite diverse, ranging from East Java, Central Java, West Java, Jakarta, Borneo, and Sumatra. Pesantren Miftahul Ula in its development now has several units of educational institutions, both formal and nonformal. Among them are islamic juniour school (MTs), Islamic senior school (MA), SMK, Islamic higher college and so on, as well as assemblies developed around the social islamic community.

As the oldest pesantren synonymous with the NU ideology, Pesantren Miftahul Ula is currently

\footnotetext{
${ }^{11}$ Suharsimi Arikunto, Prosedur Penelitian: Suatu Pendekatan Praktek, (Jakarta: Rineka Cipta. 2008), p.27.

${ }^{12}$ Interview and dialog with $\mathrm{KH}$. Abdul Qodir al-Fattah as the leader of Pesantren Miftahul Ula, Nganjuk, February 20, 2017.
}

led by the second generation, namely $\mathrm{KH}$. Abdul Qodir al-Fattah, with a moderative paradigm that is so tolerant of the cultural diversity and religiousness of its people, such as his attitude which always prioritizes deliberation in every conflict resolution by involving all interested parties in the event of blocking of LDII mosque construction by certain parties. In fact, this pesantren is a reference for non-Muslim figures such as Christians, Hindus, and Buddhists in determining social policies related to the sustainability of social harmony of Nganjuk society especially at the moments general election,village head election, social-health cooperation and so on. This moderate attitude cannot be separated from the characteristics of the founder of pesantren, namely $\mathrm{KH}$. Abdul Fattah Jalain who then passed on the leadership to his son, $\mathrm{KH}$. Abdul Qodir al-Fattah who is so tolerant as well as nurturing the living values of multiculturalism in the community by using an inclusive and dialogical approach in solving every conflict experienced by communities around the pesantren.

Moderate leadership of KH. Abdul Qodir al-Fattah was growing and reverberating along with the birth of his ideas in the founding of the Sabariman Liwetan Community Forum (FKLS), Kertosono, Nganjuk in the 2000 s after the social conflicts in mobilizing and accelerating social, economic, cultural and religious education in Nganjuk with Pesantren Miftahul Ula as its locomotive. ${ }^{13}$

\section{Profile of Pesantren al-Bidayah, Pasuruan, East Java}

Pesantren al-Bidayah is one of the 'modern' pesantren that was born in 1998 to coincide with reform movement whose impacts on Indonesia's socio-politics were quite disturbing at the time. As one of the modern pesantren in the subdistrict of Kraton, Pasuruan, East Java, Pesantren al-Bidayah, has a great commitment and concern to the problem of religious-social conflicts that previously occurred in some areas, especially in the coastal Pasuruan region where religious

${ }^{13}$ Document from FKLS Pesantren Miftahul Ula Nganjuk in 2016. 
conflicts often occur involving Sunni, Shi'ite and Wahhabism or non-Muslims.

Organizationally, Pesantren al-Bidayah is a pesantren that is identical with the ideology of Muhammadiyah, so that its approach in the settlement of social-religious conflict is relatively more 'modern', using academic discussions or seminars involving various groups that are potentially involved in conflicts and social empowerment of the surrounding community by establishing the Center for Religious Studies (CRS) as its the leading sector of peace education programs.

As a modern Islamic educational institution, Pesantren al-Bidayah Pasuruan also has a number of units of formal education institutions, from kindergarten, junior high school, and vocational school with the total number of students reaching 2400 people from several areas ranging from Java, Kalimantan and Sumatra. This pesantren is led by KH. Haris Imamuddin, MA who is an alumnus from Jordan Islamic University specializing in Islamic education. Over time, Pesantren al-Bidayah Pasuruan has been able to deliver its students to excel academically and non-academically at regional, national and even international level such as speech contest, academic writing contest, and Arabic-English debate contest, and so on. ${ }^{14}$

As a modern pesantren concerned with the social economic development of its people, Pesantren al-Bidayah Pasuruan also develops pesantren co-operative unit that can be accessed by all levels of society, both Muslims and nonMuslims, such as Christians, Hindus, and Buddhists. With the orientation of strengthening the society's social economy, Pesantren al-Bidayah hopes to strengthen the peace education program that it has developed. Building the economic foundation is a key element in strengthening community harmonization efforts, both structurally and nonstructurally. ${ }^{15}$

\footnotetext{
${ }^{14}$ Interview and dialog with $\mathrm{KH}$. Haris Imamudin, MA as the leader of Pesantren al-Bidayah, Pasuruan, April 17, 2017.

15 Interview and dialog with Idham Khalid, M.M., as the leader of Cooperation Unit in Pesantren al-Bidayah, Pasuruan, April 17, 2017.
}

\section{The Challenges of Peace Education Development for Deradicalization in Pesantren al-Bidayah and Pesantren Miftahul Ula}

Based on the result of field study and substantive analysis, it is known that the challenges of peace education development in Pesantren al-Bidayah Pasuruan and Pesantren Miftahul Ula Nganjuk, East Java in the effort of religion deradicalization include several forms that can be analyzed in a more comprehensive way as follow: first, challenge from the ideology of religious social fundamentalism. It is the ideology of religious community that views its religion as the most true religion compared to other religions/communities. This kind of ideology was actually born from a small group of mass organizations such as NU, Muhammadiyah, Persis, Indonesian Catholic Union (PKAI) and so on which has fundamentalist ideology, which cannot be regarded as representation of its own big community. ${ }^{16}$ This challenge may also be referred to as 'internal ideological challenge' that is less amenable to peace education development program of both pesantrens since the leaders of both pesantrens are 'NU and Muhammadiyah figures', although in their own local contexts. The challenge of ideology of religious social fundamentalism is still personal in nature arising from certain individuals of the existing religious organizations. Therefore, the challenge seems to be not really strong since it only comes from certain individuals who think contrary to the existing religious mindset in the organization.

This more personal challenge, however, has been gradually reduced with almost all the figures from both pesantrens (al-Bidayah Pasuruan and Miftahul Ula Nganjuk) constantly communicate across personal-religious organizations. Consequently, the movement is seen as a comprehensive effort in liquefying the frozen relationship, including in this case reducing the hatred and discriminatory feelings that sometimes arise without systematically constructed by the perpetrators themselves. What these two pesantrens have done is aligned

${ }^{16}$ Interview and dialog with M. Mustafied as the secretary of Pesantren Miftahul Ula, Nganjuk May 2, 2017. 
with one of the main goals of peace education, that is to eliminate hatred in the plurality of people. This is in line with the view of Ursula Franklin that peace is not only a lack of war, but also the creation of justice and the loss of fear and hatred within individuals and society. In addition, conflict resolution experts understand peace as not only free from the absence of war but includes economic, social and cultural justice, and free from racial, class, gender and religious discrimination as well as cooperation in the development of economic units coordinated by the two pesantrens with various communities, both across ideologies (NU, Muhammadiyah, Persis), as well as religious groups (Islam, Hinduism, Buddhism, and Christianity) which are currently growing. ${ }^{17}$

To strengthen the existence of peace education development program as well as to intensify the 'big idea' to all levels of the surrounding community, the two pesantrens establish social organization as the leading sector. Pesantren al-Bidayah which is identifial with Muhammadiyah identity established a unit of religious resolution study center which is directly managed internally by pesantren. While pesantren Miftahul Ula Nganjuk synonymous with the identity of moderate NU is directly affiliated with all heterogeneous layers of society by establishing Liwetan Culture (tradition of eating together) and developing economic units which is managed collectively with the pesantren as its coordinator.

Second, the challenge of religious political cannibalism ideology. The ideology justifies any means by placing religion as a 'tool' to realize personal/group interests, such as using religious verses to justify political interests. This challenge comes from groups and persons who have practical vested interests, both from within and outside the community groups of both pesantrens, al-Bidayah Pasuruan and Pesantren Miftahul Ula Nganjuk. This challenge is increasingly felt during the election season of head of the region, especially at the district

${ }^{17}$ Zaenal Abidin,'Teologi (Islam) Pluralis dalam Masyarakat Multi Religius", Religia Vol. 2, No. 1, May 2006, pp.15-29.
(Pilbub) and the province (Pilgub) levels. ${ }^{18}$ This challenge is faced by both pesantrens where the moment of 'political cannibalism', namely justifying any means to achieve personal political goals even at the expense of the Center for Religious Studies (CRS) at Pesantren al-Bidayah Pasuruan and Sabariman Liwetan Community Forum (FKLS) in pesantren Miftahul Ula Nganjuk is so felt that one of the indications is there are several debates of political interests of some members of CRS and FKLS in discussion forum intended to bring the forum to be used as one of the ammunition of certain political parties for their political victory.

This challenge is certainly one of the warning for CRS or FKLS itself, especially at the top leadership level to always empower various potentials that can divide and undermine its existence, both from outside and from within the organizations themselves, although until now it can be said that the leaders of both pesantrens overseeing both organizations can neutralize the threat through, among other things, the enforcement of organizational rules that the position of organization is above any interests including practical politics. Yet, anticipatory efforts need to be developed continuously, creatively and innovatively by involving all components of CRS and FKLS because every organization in any levels will undoubtedly be very vulnerable to be used by a number of parties who are less responsible for the larger organization interests, especially the new members, at the central level as self-organizational control that always wary of all potentials of practical political interests that exist in order any conflict do not happen.

Third, the challenge of exclusive religious education ideology. This challenge originates from a relatively new religious community, but has a very violent religious view which not only views the ideology of its community as 'the only true' but also behaves strictly against other communities such as the Darul Arqam community in Pasuruan and the community of

\footnotetext{
${ }^{18}$ Interview and dialog with $\mathrm{KH}$. Abdul Qodir al-Fattah as the leader of Pesantren Miftahul Ula, April 17, 2017. And also with $\mathrm{KH}$. Haris Imamuddin, MA as the leader of Pesantren alBidayah, April 27, 2017.
} 
Mujahidin al-Islamiyah in Nganjuk which, based on the results of research and police investigation, are seen as groups that contribute to the birth of terrorist movement in Indonesia. Actually, the ideology did not directly affect the peace education program developed by the two pesantrens, considering that the ideology was only its 'internal institution'. However, the community around the two pesantrens felt 'stunted' by these ideological activities which tended to be 'exclusive' and to behave as 'rebels' by holding illegal armed training. The challenge of exclusive religious education ideology that runs through the door of informal education is certainly to be addressed by both pesantrens by making the CRS and FKLS as forums of sustainable non-formal cross-religions education for young generation. The figures of CRS and FKLS since 2014 began to include students to gain knowledge continuously, even involving university institutions in the process of regeneration of peace movers. ${ }^{19}$ In other words, the two pesantrens have "earthed" their role as educator and tried to produce the nation's future generation who care about the importance of peace of the pluralist republic, including by involving the community that have played an important role such as teachers and lecturers in the environment of both formal and non-formal education.

What have been done by the two pesantrens (al-Bidayah Pasuruan and Miftahul Ula Nganjuk) in facing the exclusive religious education ideology above is in line with the essence of the crucial role of peace education which emphasize the harmony of three important pillars, namely learners/citizens, educators/figures community and parents/family. The three pillars are active actors in the process of planting noble values in building peace. Teachers and lecturers play as educators of values and science while students (members of the community) as young people who will continue the nation's sustainability are expected to play a role in the socialization of peaceful and non-violent cultural values to their

${ }^{19}$ Interview and dialog with $\mathrm{KH}$. Abdul Qodir al-Fattah as the leader of Pesantren Miftahul Ula, on 17 April, 2017. And also with $\mathrm{KH}$. Haris Imamuddin, MA as the leader of Pesantren alBidayah, April 27, 2017. peers, and parents act as partners of teachers to encourage, support and develop the actualization of a peace culture without violence. Peace education programs are channeled to conflict resolution and multicultural understandings including an activity based on the ability of individuals to argue, try to understand others and the things that underlie their thinking will be useful as tools that can be used to solve problems such as racism, discriminating or harassing others. ${ }^{20}$

In general, the challenge of peace education development by pesantren al-Bidayah Pasuruan and Pesantren Miftahul Ula Nganjuk can be described through the following chart:

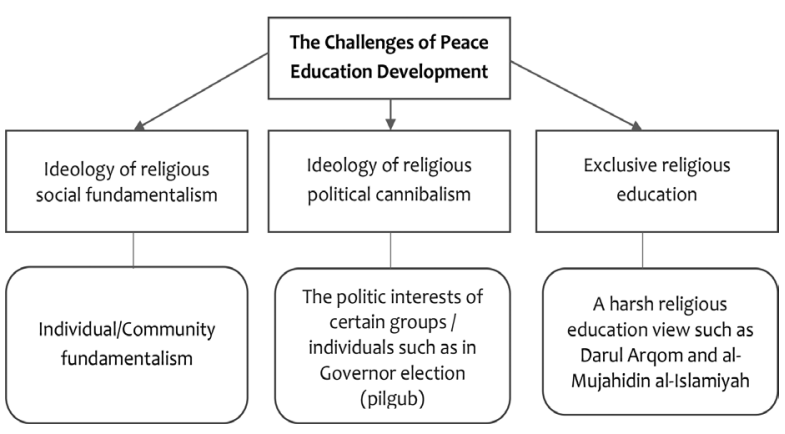

Figure 1. The Challenges of Peace Education Development in Pesantren al-Bidayah Pasuruan and Pesantren Miftahul Ula Nganjuk Jawa Timur

The various challenges of peace education development experienced by both pesantren alBidayah Pasuruan and pesantren Miftahul Ula Kertosono Nganjuk actually indicate that all the potential goods that are driven by various elements of society will certainly deal with the 'dark side' of society itself, which sometimes cannot be controlled and can also subvert the existence of the group itself. However, if the social organization is able to attach the values of togetherness as a puritan religious social movement, then the various threats that exist, whether coming from internal or external, will be a 'light' perfection for the organization, including in this case for the existence of both pesantrens.

20 Sholehuddin A. Aziz, "Penguatan Peace Building Melalui Sosialisasi Perdamaian \& Community Empowermen”, Jurnal Cendekia, Vol 8, No. 1, June 2015, pp. 1-13. 


\section{The Strategies of Peace Education Development for Deradicalization in Pesantren al-Bidayah and Pesantren Miftahul Ula}

The strategy in implementation of any programs is the 'life' of an organization. Without strategy, a mature and profane strategy of organization will undoubtedly be harder to just live and let alone to contribute. Similarly, the existence of Pesantren al-Bidayah Pasuruan and Pesantren Miftahul Ula Nganjuk does not escape from various transformation strategies in developing and achieving the goals of community organization program that has been aspired for it. In this context, the implementation of Peace Education in developing religious deradicalization efforts in Pesantren al-Bidayah Pasuruan and Peantren Miftahul Ula, Nganjuk, East Java can be explained and analyzed more comprehensively as follows: first, strategy of learning to understand cultural diversity. This strategy is done in the form of accommodating a number of cultures that live around the pesantrens. Pesantren al-Bidayah Pasuruan with its Center for Religious Studies (CRS) is more oriented towards more 'formal' forums such as Discussion and Scientific Seminar, while Pesantren Miftahul Ula Nganjuk with FKLS coordinated through more 'informal' or 'cultural' such as Liwetan program which includes Tahlilan activities, 'cleaning village', mauludan, and so on. ${ }^{21}$

The strategy to understand the cultural diversity of communities conducted by the two pesantrens, although having different approaches, has the meaning that cultural diversity that already existed is essentially a potential for peace which can be an effective medium when it can be managed wisely through the approach which is persuasive acts without having to wait for the potential to be damaged or withered due to the various actions of a handful individuals in fulfilling their personal interests. This suggests that from the beginning, the two pesantrens already have a strategy in utilizing and empowering the potential of cultural diversity of their communities which

\footnotetext{
${ }^{21}$ Interview and dialog with M. Mustafied as the secretary of Pesantren Miftahul Ula, on 17 April, 2017. And also with Muhammad Nawam as the secretary of Pesantren al-Bidayah, 27 April, 2017.
}

from the beginning has a value of peace, as well as strengthening the culture of tahlilan that involves cross Islamic ideologies (NU, Muhammadiyah, Persis) and across religions (Islam, Christianity, Buddhism and Hinduism). Or in the language of educational anthropologist lan M. Harris in his book Peace Education Theory, as a 'peace keeping strategy', where the potential of existing social harmony must be nurtured and developed to live forever, such as maintaining harmony, tolerance, etc. ${ }^{22}$

Second, the strategy of learning to understand religious plurality (diversity). This strategy is held in the form of learning other religion by making the worship place of various religions as a place of discourse, 'religious chatting', as well as the development of peace education program, either by Pesantren al-Bidayah Pasuruan and Pesantren Miftahul Ula Nganjuk East Java, like monthly religious discussions that involving cross Islamic ideologies and religions by moving from one house of a religious leader to the house of another religious figure. ${ }^{23}$ Given that religious faith in reality is one of the potential conflicts that has been 'vulnerable' to misuse and misinterpretation by some who do not understand or even ignore the importance of a peace. The misconceptions that have been misunderstood so far in the history of the pluralist republic have often become the 'spice' of horizontal conflict between elements of society, not infrequently the birth of various fundamentalism as well as terrorism, which in the end, more gloomy face of religion that is basically very emphasized peace importance on earth. And that, almost happened all over the archipelago, not least in Pasuruan and Nganjuk some time ago.

Therefore, the strategy to retrace religious face becomes very important among the community across religions and beliefs, including what has and continues to be developed by both pesantrens. This is in line with the concept of a peacebuilding strategy initiated by lan M. Harris,

${ }^{22}$ Ian M. Harris, Peace Education Theory, (Milwaukee: University of Wisconsin-Milwaukee, 2009), p.17.

${ }^{23}$ Interview and dialog with KH. Abdul Qodir al-Fattah as the leader of Pesantren Miftahul Ula, on 17 April, 2017. And also with $\mathrm{KH}$. Haris Imamuddin, MA as the leader of Pesantren alBidayah, April 27, 2017. 
which is a strategy designed to foster a sense of peace that has been lost due to social conflicts between elements of society, such as national dialogue, interreligious dialogue, etc. Essentially, this strategy is very effective in pasting the value of ice into full values of coolness. ${ }^{24}$ This is also what has been attempted by Pesantren al-Bidayah by examining the comparative material of religion by involving elements of other religions and Pesantren Miftahul Ula Nganjuk by visiting religious culture or visit other religious places of worship accompanied by discussion activities surrounding the development of religious community.

Third, the strategy of learning social economicbased community. This strategy is oriented by both pesantrens (al-Bidayah Pasuruan and Miftahul Ula Nganjuk) as an effort to develop the society's social economy without distinguishing the cultural and religious background which is expected to 'enliven' the sense of togetherness and the collective welfare of society. The orientation is according to Maulana Wahiduddin Khan's view, ${ }^{25}$ based on the principle that social economic harmony is the 'heart' of social harmony of society itself.

In that context, pesantren al-Bidayah Pasuruan established a community cooperation unit managed directly by pesantren and empowered for the benefit of all circles, while the pesantren Miftahul Ula Nganjuk as the supervisor of implementation through FKLS established by Sabariman cooperation unit which is managed collectively by involving all elements of society, both from Muslims, Christians, Buddhists and Hindus who become members, as well as in FKLS coordinated by Pesantren Miftahul Ula Nganjuk. This strategy is implemented in the form of an annual gathering, and the development of Sabariman cooperation unit where its members come from all members of the community of 315 people from 5 villages in Kertosono Nganjuk sub-district, even based on previous searches, FKLS Kertosono until now has had funds of social

\footnotetext{
24 Ian M. Harris, Peace Education Theory, (Milwaukee: University of Wisconsin-Milwaukee, 2009), p.21.

${ }^{25}$ Maulana Wahiduddin Khan, The Ideology of Peace, (New Delhi: Goodword Book, 2014), p.49.
}

organizations that reached 750 millions. ${ }^{26}$

The development of cross-religious economic activities conducted by Pesantren al-Bidayah Pasuruan and Pesantren Miftahul Ula Nganjuk emphasized how the role of community's economic sector is so vital in strengthening the fabric of cooperation of its members like 'one big family', full of values of togetherness and cooperation social economy that coincides and strengthenes the wheels of tits member's economy, like many of the home-made crackers businesses of its members that significantly increased and also successfully opened branches and helped to provide new jobs to the poor people around pesantrens. With this program, the relationship between members is more closely and more understanding with each other. So that, the divide of religious, ethnic and cultural differences even more merged into a unity as the main power of Center for Religious Studies (CRS) Pesantren al-Bidayah and pesantren Miftahul Ula through FKLS. This is in line with Ian M. Harris's third draft strategy, about the importance of a peace-making strategy, or a peace-building strategy. This strategy is designed to follow up the 'dividing wall' between certain communities even though it does not give rise to social conflict in the hope that the emergence of 'social communication between communities' which in the end is expected to arise cooperation across social communities. ${ }^{27}$

Some strategies of peace education development implemented by both pesantrens can be described through the following chart:

\footnotetext{
${ }^{26}$ Interview and dialog with M. Mustafied as the secretary of pesantren Miftahul Ula, Nganjuk, April 17, 2017

${ }^{27}$ Maulana Wahiduddin Khan, (The Ideology of Peace, New Delhi: Goodword Book, 2014), p.61.
} 


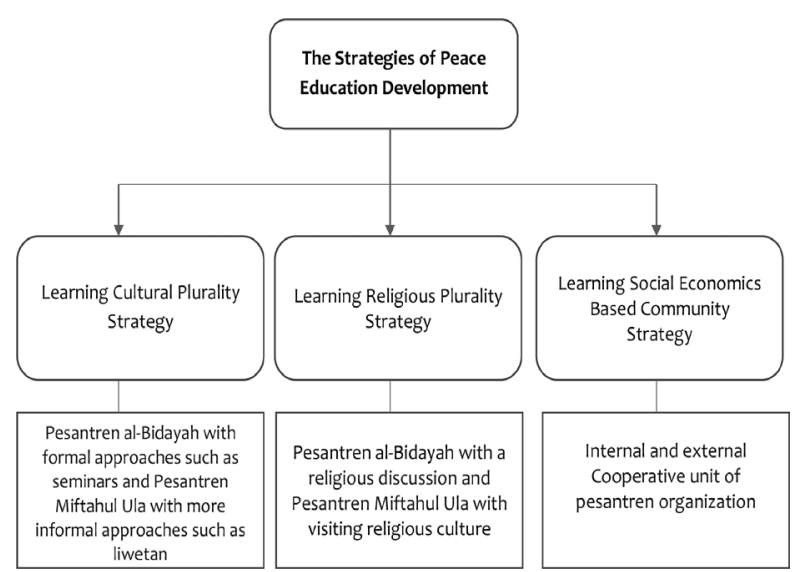

Figure 2. The Strategies of Peace Education Development in Pesantren al-Bidayah Pasuruan dan Pesantren Miftahul Ula, Nganjuk East Java

From the analysis of peace education development strategies designed and implemented by both pesantrens, it can be concluded that peace education is one of the learning efforts that can contribute and be able to create better citizens in this world. The transformation process is by inculcating a philosophy of mutual support, commitment, mutual cooperation as well as teaches cross-cutting peace without the despair of violence, hatred and discrimination which also means to protect the environment and life together as human beings. This is also in harmony with Furlong's views in his book, The Conflict Resolution Toolbox that peace education provides an alternative by teaching citizens how violence can occur and informing them about the critical issues of peace education that can accommodate the wider potentials and interests of society. ${ }^{28}$

\section{The Contributions of Peace Education Development for Deradicalization in Pesantren al-Bidayah and Pesantren Miftahul Ula}

In any action, a program organized by an organization will undoubtedly has an impact or contribution to the existence of organization itself, both positive and negative. No exception in this regard is the contribution of peace education development in the effort to religion deradicalization perceived by Pesantren al-Bidayah

28 Gary T. Furlong, The Conflict Resolution Toolbox. (Canada: John Wiley \& Sons Canada, Ltd. 2005), p.81.
Pasuruan and Pesantren Miftahul Ula, Nganjuk East Java and the communities around the two pesantrens. A number of contributions can be analyzed as follows: first, the contribution of the birth of non-violence culture for the communities around the two pesantrens. This can be proved by the fact that since 2000 until now, there almost never happened any cases of violence acts in the community. For example, in the sub-district of Keraton, Pasuruan, there are three assisted villages that became the basis for peace education development conducted by pesantren al-Bidayah. The three villages are Keraton, Asahan and Manisrejo villages with a total membership of 249 people. In other side, as for the communities around pesantren Miftahul Ula Nganjuk, there are five villages in Kertosono sub-district, which is the basis of peace-educated villages community with 320 members consisting of Nglawak, Lambangkuning, Plimping, Banaran and Sananrejo villages. These villages even tends to be pilot villages in the field of social harmony development. ${ }^{29}$

This fact organizationally confirms that peace education which has been developed by pesantren al-Bidayah Pasuruan coordinated by CRS and pesantren Miftahul Ula, Nganjuk through FKLS is able to 'touch' the heart of society to the grassroots who had been viewed as a party that is prone to potential horizontal conflict. Besides that, according to Charles F. Howlett, ${ }^{30}$ the building of social harmony between members as well as with the community at large suggests that the various peace education programs implemented are able to enlighten everyone that peace is essential to a common life, not only for the moment but also for the future harmony of nation's children.

Second, the contribution of development of respect culture for human rights in the

${ }^{29}$ Interview and dialog with $\mathrm{KH}$. Abdul Qodir al-Fattah as the leader of Pesantren Miftahul Ula, on 17 April, 2017. And also with $\mathrm{KH}$. Haris Imamuddin, MA as the leader of Pesantren alBidayah, April 27, 2017.

${ }^{30}$ Charles F. Howlett, John Dewey and Peace Education, (Columbia: Columbia Univerity, 2008), p.109. See also Mohd Yaseen Gaad, “On pluralism, religious 'other', and the Quran: A Post September-11 Discourse," Indonesian Journal of Islam and Muslim Societies Vol. 6, No. 2, December 2016, pp..241-271. 
communities around the two pesantrens. This can also be proved by the form of public appreciation of village head election from different religious backgrounds from 8 villages with Muslim majority, three of them led by Christians, and one village with Christian majority led by a Muslim with consideration of owning good performance. ${ }^{31}$ This phenomenon at once confirms to the public that 'difference' is not something that is fundamental in realizing a peace of society, but 'understanding substantive differences' is the key to the birth of mutual respect as fellow human beings as well as fellow children of the nation who have same rights and obligations. So, the above phenomenon increasingly states the fundamental role of peace education conducted by pesantren al-Bidayah and pesantren Miftahul Ula as a necessity to foster the importance of respecting human rights, both personally and collectively.

What is done by pesantren al-Bidayah, Pasuruan and Pesantren Miftahul Ula, Nganjuk is a real action in realizing the climatic orientation that is full of true harmony and peace. Without any respect for human rights in any membership of the organization, it is not impossible that there will be horizontal conflicts where religion is used as the most 'eloquent' tool for discriminating other people's rights. Such understanding could trigger and potentially lead to riot and conflict between religious communities. Radical acts in the name of religion are very likely to occur in these circumstances. Therefore, peace education that teaches about reality of religious, ethnic, cultural, and linguistic diversity (pluralism) that must be managed and respected will be able to keep away from extreme and radical attitudes and actions. This means peace education can be a tool of deradicalizing people's religiousity, ${ }^{32}$ as illustrated by what have been done by pesantren al-Bidayah and pesantren Miftahul Ula.

Third, the contribution for the establishment

${ }^{31}$ Interview and dialog with M. Mustafied as the secretary of Pesantren Miftahul Ula, on 17 April, 2017. And also with Muhammad Nawam as the secretary of Pesantren al-Bidayah, April 27, 2017.

32 Hans Kung. Tak Ada Perdamaian Dunia Tanpa Perdamaian Agama-agama, dalam Jalan Dialog Hans Kung dan Presfektif Muslim, (Yogyakarta: Public Lecture Hans Kung CRCS UGM, 2010), p.4. of democratic values and tolerance. This can be proved by giving full freedom to all members to elect leaders, either in the election of village heads, regents, even prospective leaders on CRS or FKLS in both pesantrens (al-Bidayah and Miftahul Ula) where every four years leadership. ${ }^{33}$ This confirms that peace education developed by both pesantrens also provides understanding and awareness to its members and the surrounding community about the importance of "active peace" in the life of a very diverse community.

The attitude of "active peace" in this context does not mean simply letting others exist, but also developing togetherness and mutual understanding. Thus, peace becomes the minimum means or basic capital for the realization of interreligious relationships of mutual respect and awareness. With this, according to Sahid Imanullah Khan ${ }^{34}$, automatically radical attitudes that lead to religious conflicts one against other people's religion can be eliminated, and this means that the deradicalization process undertaken by the two pesantrens has found results where one of the indicators is awakening awareness of the importance of democratic values and tolerance among them ultimately also leads to a sense of peace that can be shared.

This can also be proved by the life of all religious cultures of NU, Muhammadiyah, LDII, Hindu, Christian, and Buddhist communities, such as cultural-religious seminars, tahlilan, maulidan, 'cleaning village', and so on. Portraits that occur and developed by both pesantrens insist that religious pluralism in life is a necessity. This is because diversity is God's revelation and human acceptance and expression of that revelation. This is similar to Alwi Shihab's view which asserts that pluralism is essentially a substantive mirror of diversity. Or in his scientific language, "the principle that differences in racial, political and

33 Interview and dialog with M. Mustafied as the secretary of Pesantren Miftahul Ula, on 17 April, 2017. And also with Muhammad Nawam as the secretary of Pesantren al-Bidayah, April 27, 2017.

34 Sahid Imanullah Khan, Peace Education in Contemporary Moslem Society, (New Delhi: Islamabat Press, 2016), p.71. See also Mohammad Takdir Ilahi, Nasionalisme dalam Bingkai Pluralitas Bangsa: Paradigma Pembangunan dan Kemandirian Bangsa, (Yogyakarta: Ar-Ruzz Media, 2012), p.79. 
religious differences can coexist peacefully in one society". ${ }^{35}$ While religious pluralism is not merely a fact about religious diversity and all its differences, it is closely related to the assumptions and judgments of a particular religion on the existence of other religions. This is what shapes the attitude of a religious person in looking at other religions. ${ }^{36}$

For that reason, the understanding of diversity does not lead to the horizontal conflict, then what is conducted by pesantren al-Bidayah and Pesantren Miftahul Ula is correct by giving understandings to its members and the surrounding community about the importance of understanding the existence of cultural diversity and religions which exists as a sunnatullah to enable humanity to live side by side while strengthening one another for the common purpose. This fact at once confirms the view of Harris $^{37}$ that the pesantren organization is also increasingly affirming its basic capital which is very mature in developing the peace values with various approaches and strategies that they have.

Below is a table that describes the simple point of intersection and the difference of challenges, strategies and contributions of peace education that have been developed by Pesantren al-Bidayah Pasuruan and Pesantren Miftahul Ula Nganjuk.

Table 1. The Difference and Intersection of Peace Education Development managed by Pesantren al-Bidayah dan Pesantren Miftahul Ula

\begin{tabular}{|c|c|c|c|c|c|}
\hline No. & Challenge & Strategy & Contribution & Difference & Intersection \\
\hline 1. & $\begin{array}{l}\text { Ideology of } \\
\text { religious social } \\
\text { fundamentalism }\end{array}$ & $\begin{array}{l}\text { Learning } \\
\text { Cultural } \\
\text { Plurality } \\
\text { Strategy }\end{array}$ & $\begin{array}{l}\text { The birth of } \\
\text { non-violence } \\
\text { culture for the } \\
\text { communities } \\
\text { around the } \\
\text { two pesantrens }\end{array}$ & $\begin{array}{l}\text { Strategy: } \\
\text { Pesantren } \\
\text { al-Bidayah } \\
\text { uses formal } \\
\text { approaches } \\
\text { such as } \\
\text { seminars } \\
\text { while } \\
\text { Pesantren } \\
\text { Miftahul Ula } \\
\text { adopts more } \\
\text { informal } \\
\text { approaches } \\
\text { such as } \\
\text { liwetan } \\
\text { tradition }\end{array}$ & $\begin{array}{l}\text { Challenge: } \\
\text { Individual/ } \\
\text { Community } \\
\text { fundamentalism } \\
\text { Contribution: } \\
\text { No violence } \\
\text { and } \\
\text { discrimination } \\
\text { impacted to } \\
\text { communities } \\
\text { around two } \\
\text { pesantrens } \\
\text { since } 2000\end{array}$ \\
\hline
\end{tabular}

${ }^{35}$ Sahid Imanullah Khan, Peace Education in Contemporary Moslem Society..., p.112.

36 Zaenal Abidin,"Teologi (Islam) Pluralis dalam Masyarakat Multi Religius", Religia Vol. 2, No. 1, May 2006, p.4.

${ }_{37}$ Ian M. Harris, Peace Education: Colleges and University, Encyclopedia of Violence, Peace, and Conflict, Volume 2, (Milwaukee: University of Wisconsin-Milwaukee, 2007), p.29.

\begin{tabular}{|c|c|c|c|c|c|}
\hline 2. & $\begin{array}{l}\text { Ideology } \\
\text { of religious } \\
\text { political } \\
\text { cannibalism }\end{array}$ & $\begin{array}{l}\text { Learning } \\
\text { Religious } \\
\text { Plurality } \\
\text { Strategy }\end{array}$ & $\begin{array}{l}\text { The } \\
\text { Development } \\
\text { of respect } \\
\text { culture } \\
\text { for human } \\
\text { rights in the } \\
\text { communities } \\
\text { around the } \\
\text { two pesantrens }\end{array}$ & $\begin{array}{l}\text { Strategy: } \\
\text { Pesantren al- } \\
\text { Bidayah uses } \\
\text { a religious } \\
\text { discussion } \\
\text { while } \\
\text { Pesantren } \\
\text { Miftahul Ula } \\
\text { uses visiting } \\
\text { religious } \\
\text { culture }\end{array}$ & $\begin{array}{l}\text { Challenge: } \\
\text { The political } \\
\text { interests of } \\
\text { certain groups/ } \\
\text { individuals } \\
\text { such as in } \\
\text { Governor } \\
\text { election } \\
\text { (pilgub) } \\
\text { Contribution: } \\
\text { the birth of } \\
\text { humanist } \\
\text { communities } \\
\text { around two } \\
\text { pesantrens }\end{array}$ \\
\hline 3. & $\begin{array}{l}\text { Ideology of } \\
\text { Exclusive } \\
\text { religious } \\
\text { education }\end{array}$ & $\begin{array}{l}\text { Learning } \\
\text { Social } \\
\text { Economic- } \\
\text { Based } \\
\text { Community } \\
\text { Strategy }\end{array}$ & $\begin{array}{l}\text { The } \\
\text { establishment } \\
\text { of democratic } \\
\text { and tolerance } \\
\text { values }\end{array}$ & $\begin{array}{l}\text { Strategy: } \\
\text { Pesantren } \\
\text { al-Bidayah } \\
\text { uses Internal } \\
\text { Cooperative } \\
\text { unit while } \\
\text { Pesantren } \\
\text { Miftahul } \\
\text { Ula adopts } \\
\text { external } \\
\text { cooperative } \\
\text { unit }\end{array}$ & $\begin{array}{l}\text { Challenge: } \\
\text { radical } \\
\text { religious } \\
\text { education } \\
\text { views such as } \\
\text { Darul Arqom } \\
\text { in Nganjuk and } \\
\text { al-Mujahidin } \\
\text { al-Islamiyah in } \\
\text { Pasuruan } \\
\text { Contribution: } \\
\text { The birth } \\
\text { of tolerant } \\
\text { and inclusive } \\
\text { people that } \\
\text { appriciate } \\
\text { differences, } \\
\text { like culture } \\
\text { of tahlilan, } \\
\text { mauludan, } \\
\text { discussion, and } \\
\text { so on. }\end{array}$ \\
\hline
\end{tabular}

\section{Conclusion}

The challenges of peace education development in the efforts of religion deradicalization in Pesantren al-Bidayah Pasuruan and Pesantren Miftahul Ula, Nganjuk, East Java cover several forms: (a) the ideology of religious social fundamentalism. This challenge comes from a religious community that views its religious ideology as most true values than other communities. This kind of ideology is born from a small circle of mass organizations such as NU, Muhammadiyah, Persis, the Indonesian Catholic Union (PKAI) and so on which has a fundamentalist ideology, which cannot be considered to represent the ideology of its own great community; (b) the ideology of religious political cannibalism. These challenges come from a group and individuals who have practical political lust, both from within and outside Sabariman's liwetan community groups; and (c) the ideology of exclusive religious education. This challenge originates from a relatively new religious community, but it has a very violent religious view which not only views the ideology of its community as 'the only true one' but also behaves strictly against other communities, such as the Darul Arqam community Nganjuk, community of Mujahidin al-Islamiyah Pasuruan, East Java. 
The strategies of peace education development in the effort of religion deradicalization in pesantren al-Bidayah Pasuruan and Pesantren Miftahul Ula, Kertosono, Nganjuk, East Java cover several things which include: (a) strategy of learning culture plurality. This strategy is carried out in the form of accommodating a number of cultural communities living around the two pesantrens framed in scientific discussion activities and liwetan culture that include tahlilan, 'cleaning village', mauludan, and so on; (b) strategy of learning religious plurality. This strategy is one of them organized in the form of learning other religion by making the worship place of various religions as a place of discourse, and 'social chatting'; and (c) strategy of learning social economic-based community. This strategy is implemented in the form of annual gathering and the development of al-Bidayah pesantren co-operative unit and Sabariman community co-operative unit (Pesantren Miftahul Ula).

The contributions of peace education development in religious deradicalization efforts in pesantren al-Bidayah, Pasuruan and pesantren Miftahul Ula, Nganjuk, East Java cover several important things, namely: (a). The birth of nonviolence culture in the liwetan community of Sabariman, Kertosono Nganjuk. This can be proved by the fact that from 2000 until today, in 8 villages in Kertosono, Nganjuk and Sanarejo sub-districts, Pasuruan, which has been a builtin village, has never been a case of violence. In fact, these villages tend to be pilot villages in the field of social harmony; (b). The development of a respect culture for human rights. This can also be proved by the form of public appreciation of village heads election from different religious backgrounds from five villages with Muslim majority, two of them are led by Christians, and one village with Christian majority is led by a Muslim with the consideration of having good performance; (c). awakening of democratic values and tolerance. This can be proved by granting full freedom to all members to elect leaders, either in the election of village heads, regents, and even the leaders of Sabariman's own liwetan community where every four years there is a change of leadership and also the life of all religious cultures derived from NU, Muhammadiyah, LDII, Hindu, Christian, and Buddhist, such as cultural discussions, Tahlilan, Maulidan, 'cleaning village', and so on;

\section{References}

Abidin, Zaenal,"Teologi (Islam) Pluralis dalam Masyarakat Multi Religius", Religia Vol. 2, No. 1, May 2006.

Arikunto, Suharsimi. Prosedur Penelitian: Suatu Pendekatan Praktek. Jakarta: Rineka Cipta. 2008.

Aziz, Sholehuddin A, "Penguatan Peace Building Melalui Sosialisasi Perdamaian \& Community Empowermen", Jurnal Cendekia Vol. 8, No. 1, June 2015.

Azra, Azyumardi Azra, "Rekruitmen Anak Sekolah”, Republika, April 24, 2012.

Bogdan, R.C., \& Biklen, S.K. Qualitative Reseach for Education: An Introduction to Theory and Methods. London: Allyn and Bacon, Inc. 1998.

Buletin Ulul Albab, Pesantren Miftahul Ula, Kertosono, Nganjuk, East Java, January, 2017

Buliten Ar-Risalah, Pesantren al-Bidayah, Pasuruan, East Java, July 2016.

Darmawan, Josep J, (ed.), Multikulturalisme Membangun Harmoni Masyarakat Plural, Yogyakarta: Universitas Atma Jaya Yogyakarta, 2014.

Department of International \& Transcultural Studies, Fundamental Concepts of Peace Education, Columbia: Columbia Univerity, 2010.

Document of Balai Litbang Kemenag in 2017 dalam www/http.balitbang.kemenag.go.id. downloaded on 13 April 2017

Document of Forum Komunitas Liwetan Sabariman (FKLS) Pesantren Miftahul Ula Nganjuk in 2016.

Furlong, Gary T, The Conflict Resolution Toolbox, Canada: John Wiley \& Sons Canada, Ltd. 2005.

Garcia, Ricardo L, Teaching in Pluralistic society, New York: Harper \& Row Plubisher, 2012.

Gaada, Mohd Yaseen, "On pluralism, religious 'other', and the Quran: A Post September-11 Discourse," Indonesian Journal of Islam and Muslim Societies (IJIMS) Vol. 6, No. 2, December 2016. 
Harris, Ian M, Peace Education Theory, Milwaukee: University of Wisconsin-Milwaukee, 2009.

Harris, Ian M, Peace Education: Colleges and University, Encyclopedia of Violence, Peace, and Conflict, Volume 2, University of WisconsinMilwaukee, 2007.

Howlett, Charles F, John Dewey and Peace Education, Columbia: Columbia Univerity, 2008.

Ihsan, M. Nurul, Peace Education dan Relevansinya dengan Pendidikan Islam, Yogyakarta: Fakultas Tarbiyah dan Keguruan UIN Sunan Kalijaga, 2012.

Ilahi, Mohammad Takdir, Nasionalisme dalam Bingkai Pluralitas Bangsa: Paradigma Pembangunan dan Kemandirian Bangsa, Yogyakarta: Ar-Ruzz Media, 2012.

Khan, Maulana Wahiduddin. The Ideology of Peace. New Delhi: Goodword Book, 2014.

Khan, Sahid Imanullah, Peace Education in Contemporary Moslem Society, New Delhi: Islamabat Press, 2016.

Kung, Hans. Tak Ada Perdamaian Dunia Tanpa Perdamaian Agama-agama, dalam Jalan Dialog Hans Kung dan Presfektif Muslim. Yogyakarta: Public Lecture Hans Kung CRCS UGM, 2010. Mahfudz, Choirul, Pendidikan Multikultural, Yogyakarta: Pustaka Pelajar, 2013.

Naim, Ngainun, "Strategi Penanganan Radikalisme dan Terorisme di Indonesia: Perspektif Pendidikan", National Simposium on "Memutus Mata Rantai Radikalisme dan Terorisme", Jakarta, 15 July 2012. Syarif Hidayatullah State Islamic University of Jakarta.
Philip, Michael, Peace Education on Social Media Challenge, New York: Wilcohn Press, 2016.

Reardon, Betty A, Comprehensive Peace Education; Educationg for Global Responsibility, New York, Columbia University: Teacher College Press, 2014.

Republika, 23 March, 2018.

Shihab, Alwi, Islam Inklusif Menuju Sikap Terbuka dalam Beragama, Bandung: Mizan, 1998.

Sukmadinata, Nana Syaodih. Metode Penelitian Pendidikan. Bandung: Remaja Rosdakarya. 2006.

The Wahid Institute, "Terorisme dan Radikalisme: Tantangan Kekinian Islam Nusantara”, on National Seminar, Jakarta, 19 Augustus, 2016. Syarif Hidayatullah State Islamic University of Jakarta.

Thoyib, Muhammad. Model Pengembangan Pendidikan Islam Multikultural di Indonesia. Ponorogo: STAIN Po-Press. 2016.

Tilaar, H. A. R, Multikulturalisme: Tantangantantangan Global Masa Depan dalam Transformasi Pendidikan Nasional, Jakarta: Grasindo, 2010.

Yaqin, M. Ainul, Pendidikan Multikultural: Cross Cultural Understanding untuk Demokrasi dan Keadilan, Yogyakarta: Pilar Media, 2013. 